\title{
Entrepreneurial Ecosystem and Regional Competitive Advantage: A Case Study on the Creative Economy of Indonesia
}

\author{
Ratih Purbasari \\ Faculty of Administrative Sciences, \\ University of Indonesia, Depok, West Java, Indonesia \\ Chandra Wijaya \\ Department of Business Administration, \\ University of Indonesia, Depok, West Java, Indonesia \\ Ning Rahayu \\ Department of Fiscal (Tax) Administration, \\ University of Indonesia, Depok, West Java, Indonesia
}

\begin{abstract}
This investigation employs Indonesia's creative economy sector as a case study to discover how an entrepreneurial ecosystem promotes competitive advantage (CA) and to ascertain the elements involved within the entrepreneurial ecosystem and their functions. Each actor's role in encouraging CA in Indonesia's creative economy is explained, analyzed, and deduced. The results reveal that entrepreneurship and culture are the major contributors to CA. The government's regulations and policies supporting entrepreneurial activities are also pivotal although access to markets still need to be built. Finally, this paper states the implications of this study for scholars and practitioners and provides future research directions.
\end{abstract}

Keywords: entrepreneurial ecosystem; regional competitive advantage; creative economy; entrepreneurship; Indonesia.

\section{INTRODUCTION}

Globalization mandates that enterprises must compete beyond their national boundaries. To do so successfully, companies must focus on their unique and sustained resources [42] to create sustained competitive advantage (CA). They must further adapt and update their knowledge to maintain their CA in the face of rapid changes [14]. CA can be achieved by intensifying the direct and indirect capabilities of a company for intensive production, by updating knowledge and increasing productivity, through innovation, and through the formation of new firms that accompany the integration of local and global value chains [17]. Drucker [48] also posits the knowledge-only source of an enterprise's CA [41].

With regard to SME development and entrepreneurship, economic policy should attend to increasing competition, to the creation of employment, and to fiscal development in existing cases. On the other hand, public policy should concentrate on creativity, innovation, and economic growth [61], particularly in the creative economy sector. The term 'creative economy' applies to an industry that is based on inventiveness and innovation in the processing of natural resources and in making use of the surrounding environment. Creativity and innovation add value to products and create a positive impact on the economy and on the social life of the community [50]. A creative economy seeks sustainable development through the use of human ingenuity. To be sustainably developed, the economic climate must be 
competitive and must have access to renewable resource reserves [58]. The development of a creative economy in various countries exhibits significant positive results in employment, as well as an increase in regional income and regional imaging in the international arena. Regional imagery emerges when a particular part of the world becomes famous because of the creative products it produces [46].

The creative economy sector in Indonesia has grown and developed into a crucial economic sector. According to data obtained from the 2015 Central Statistics Agency (BPS), the creative economy absorbed 15.9 million workers (13.90\%) and produced an export value of US\$ 19.4 billion (12.88\%). According to a survey conducted by the BPS and the Creative Economy Agency (Bekraf), the creative economy contributed Rp 920 trillion to the GDP at the end of 2016, a figure that is expected to reach Rp 1,000 trillion in 2017. The development of the creative economy in Indonesia is supported by the Instruction Number 6 of the President of the Republic of Indonesia delivered in 2009. The 16 subsectors that are expected continue to develop between 2015 and 2019 are: performing arts, fine arts, television and radio, game applications, architecture, interior design, visual communication design, advertising, music, publishing, photography, product design, fashion, animated films and other video entertainment, and the craft and culinary sectors [11].

The master plan for the development of the creative industry until 2025 mandates that the direction of the 2015-2019 creative industry is to strengthen its progress emphasizing the achievement of CA through the excellence of natural resources, high- quality culture, human resources, and ingenuity in utilizing science and technology. In addition, the master plan aims to strengthen institutions to create a business climate conducive to the development of local creative industries. However, changes and macro- economic turmoil have significantly influenced Indonesia's competitiveness [11], and the growth of the creative economy still faces varied obstacles. The "Creative Economy Master Plan: Indonesia's New Power toward 2025" identifies seven pivotal issues that pose challenges to creative economic development: creative human resources, raw material, industrial competitiveness, financing, markets, infrastructure and technology, and institutional and business climate [10].

According to the World Economic Forum (WEF) reports 2009-2015, Indonesia's global competitiveness index is fluctuating: in 2015, Indonesia was ranked 37th out of the 140 countries assessed. Indonesia ranked 54th in 2009, rose to 44th in 2010, dropped to 46th in 2011,50 th in 2012, and moved up to 38th in 2013. In 2014, Indonesia's competitiveness index rose to 34th. Based on the 2015 WEF report, many factors caused the vulnerability of Indonesia's industrial competitiveness. Of these problems or factors, 10 primarily affect Indonesia's competitiveness and its business climate: corruption, bureaucratic inefficiencies, lack of infrastructure, inconsistent and changing policies, ease of access to finance, tax rates, high inflation, too many tax regulations, low-quality HR, and exchange rate policies that are not significant. Consequently, the effects of such factors also influence the development of creative industries $[58,70]$.

The development of a creative economy requires qualified human resources with innovative power and ingenuity [46]. Human resources that are capable of productive entrepreneurship should encourage job creation through the creativity of CEOs who have an entrepreneurial spirit, excellent knowledge, and technological skills. This type of entrepreneurship is crucial to the growth of local entrepreneurial ecosystems that drive competitiveness excellence [37]. As an approach that can promote $\mathrm{CA}$, an entrepreneurial ecosystem comprises a self-trusting network system that is useful for the development of policies to support competition [34]. This approach has the potential to "replace" or even precondition cluster strategies, innovation 
systems, knowledge-based economies, and national competitiveness policies [35]. Several empirical studies evince the manners in which a superior entrepreneurial ecosystem enables the creation of entrepreneurial quality and competitive value at the regional level [67]. Mack and Mayer [43] explored the contribution of early entrepreneurial success in Phoenix, Arizona to a persistent entrepreneurial ecosystem based on real success stories, strong entrepreneurial culture, and supportive public policies. Similarly, Spigel's research [62] in Waterloo and Calgary, Canada, demonstrated that although ecosystems can have different structures and origins, their success vests in their ability to create cohesive social and fiscal systems that support the creation and growth of new businesses [64]. A business model that builds an entrepreneurial ecosystem for a creative economy can enable the development of an entrepreneurial platform that would act as a catalyst for innovative economics [37].

However, discussion is limited on the ways in which the entrepreneurial ecosystem can develop a creative economy, which is recognized to wield the power to economically advance both developed and developing countries. The present research initiative aims to reveal the manner in which an entrepreneurial ecosystem promotes CA by using the creative economy sector in Indonesia as a case study. This investigation identifies the roles played by elements within the entrepreneurial ecosystem in the creative economy of Indonesia. The case study is applied to ascertain the elements involved within an entrepreneurial ecosystem and their functions. The role of each actor involved in the entrepreneurial ecosystem in Indonesia's creative economy in encouraging CA is documented, explained, analyzed, and deduced. This paper further details the implications of this investigation for scholars and practitioners and provides directions for future research.

\section{LITERATURE REVIEW}

Entrepreneurial Ecosystems (EE). Moore [45] assumed the concept of ecosystems from the point of view of business organizations with specific reference to business networks, and states that ecosystems are a response to the need to promote innovation and creativity and find answers to economic and social problems. Iansiti and Levien [30] extend Moore's concept by defining the role of the actors in a business ecosystem by linking them to the collective nature of their ecosystem [47]. This network of relationships involves varied players who interact and contribute to the performance of the community or region, provide opportunities for new businesses, and describe the limits of entrepreneurial action [69]. In so doing, these actors cause the sustainability of the entrepreneurial ecosystem itself [3].

The widely applicable definition of an entrepreneurial ecosystem recognizes that it comprises a set of coordinated actors and interdependent factors that enable the realization of entrepreneurship. Actors and factors relate to the availability of real and potential knowledge, investors, human resources, culture, infrastructure, institutions, regulations, fiscal conditions, social and environmental quality, and the ability to produce innovation [47]. Mason and Brown [44] explain that the entrepreneurial ecosystem is a set of relationships between entrepreneurs, entrepreneurial organizations, entrepreneurial institutions and entities that formally and informally join together to interact, mediate, and regulate entrepreneurial performance in the local entrepreneurial environment. Stam [63] defines the entrepreneurial ecosystem as a set of actors and related and coordinated factors that produce productive entrepreneurship. Isenberg [34] proposes a model for an entrepreneurial ecosystem that consists of elements that can be grouped into six domains of conducive culture. These elements facilitate policy and leadership, and make special finance, relevant human capital, and business-friendly markets available for products. They also assist obtaining access to a wide range of institutional and infrastructure support. Spigel [62] argues that the entrepreneurial ecosystem consists of 11 cultural, social, and material attributes that provide benefits and 
resources to entrepreneurs. The 11 attributes are supportive culture, entrepreneurial history, employee talent, investment capital, networks, mentors and role models, policies and government, universities, support services, physical infrastructure, and open markets.

The existence of an institution is a necessary but insufficient condition for a strong and competitive entrepreneurial ecosystem [36]. Once determined by time, space, and a set of resources, competition is now increasingly determined by the quality of strategic thinking with regard to opportunities, challenges, core competencies, capabilities, and the arena of corporate competition. The executive must navigate the constantly changing arena of competition that is no longer determined by physical or even digital dimensions, but by global networks and ecosystems in regions where companies compete [73]. Contending within an ecosystem demands the synchronization of strategic thinking and entrepreneurship; together, they create new knowledge that supports both business activities and calculated cognition $[30,73]$.

Regional Competitive Advantage. Contemporary views on CA include two schools of thought: one argues that competitiveness is determined by the main input factors of a company; the other claims that macroeconomic aspects such as public policy, infrastructure, and economic growth are the main pillars of CA [61]. CA varies across geographical space, and regions develop at different levels depending on the drivers of economic growth [26]. Cellini and Soci [56] assert that the idea of regional CA is not macroeconomic (national) or microeconomic (company based). CA takes on different meanings according to the scale or level at which the term is used. Therefore, it is distinguished by the competitive levels of macro (country), micro (individual companies), and meso (local economic systems), where the latter is subdivided into industrial districts (that Porter calls "clusters"), and territories [16].

Camagni [55] states that an area can be considered to have an absolute CA when it commands superior technological, social, infrastructural, or institutional assets that are external but that benefit individual companies. No alternative prices will cause a geographic redistribution of activities in such cases and so, the economy is encouraged to move toward increased productivity [16]. According to Porter [51] the only concept of meaningful competitiveness is productivity. The sustainable growth of productivity requires continuous economic improvement [16].

Regional CA refers to conditions that allow companies to compete in the markets they choose and also to the value captured and generated by these companies in an area [27]. It consists of the ability of an economy to attract and to retain a company with a stable or increasing market share in an activity while maintaining a constant or increasing standard of living for the participants [59]. Regions with institutions and cultures that are conducive to entrepreneurship can also increase CA by attracting investment, skills, and talent [68]. Culture shapes what individuals view to be opportunities; therefore, entrepreneurial attention is also related to judgment, creativity, and interpretation [26]. Regions with strong entrepreneurial traditions gain CAs if they are able to perpetuate their benefits over time and across generations $[40,26]$. CA is increasingly concerned with creativity, knowledge, innovation, and environmental conditions, but it is not purely gained on the basis of accumulated wealth [27].

Creative Economy. Toffler's theory states that human civilization is divided into three waves: the first represents agriculture; the second pertains to the industrial era; and the third signifies the information age. Toffler stops at this point. As theories continue to develop, high competition and globalization directs human civilization toward a fourth wave that some scholars have labeled the knowledge-based economy, while others describe it as the creativityoriented or creative economy [65]. 
A discussion on the creative economy cannot be separated from an elaboration on the creative industry. The creative industry is an aspect of the creative economy because ingenuity is relevant for all sectors of economy and society. Dubina et al. [21] state that the more advanced and mature a knowledge economy (creativity economy) and a knowledge society (creativity community), the more wisdom, innovation, and creativity can be absorbed and even demanded for further progress. A creative economy is intertwined with technological and social innovation [15]. Piergiovanni, Carree and Santarelli [49] reveal that creativity is a multifaceted imaginative resource that displays economic, cultural, and technological features. To improve local economy, creativity must be transformed into economic and social value [8].

A creative economy is an ecosystem that exhibits a relationship of interdependence between an inventive value chain, a development environment (nurturing environment), a market (market), and archiving. Therefore, a creative economy can improve CA and also ameliorate the quality of life [58]. Resourceful economics is expected to grow in a strong creative economic ecosystem to promote CA.

The Role of an Entrepreneurial Ecosystem in Promoting Regional Competitive Advantage. An entrepreneurial ecosystem can promote CA because it is composed of a self-trusting network system that is useful for the development of policy that supports competition [34]. In addition, the entrepreneurial ecosystem is a dynamic economic model that can be utilized in the strategic planning process. It provides a framework for reciprocal relations among the involved stakeholders and defines customer needs which can, in the future, ensure an increase in value propositions [32]. The essence of the entrepreneurial ecosystem strategy depends on the factors that shape the entrepreneurial ecosystem and the manner in which it evolves. The entrepreneurial ecosystem consists of a dozen or more elements with unique combinations interacting in complex ways to produce independent entrepreneurship. Policy and leadership, a conducive culture, the availability of special financing, relevant human capital, businessfriendly markets for products, and a series of institutional and infrastructure support are required to support this outcome [35].

The most referenced entrepreneurial ecosystem model is proposed by Isenberg [35]. It presents six interrelated fields and describes the roles of actors as follows [20,53]:

1) Policy: The government's function is to remove barriers and to provide the ideal preconditions for entrepreneurial development $[35,44]$. This precondition relates to reforms in the legal, bureaucratic, and regulatory framework [34]. The simplification and organization of tax collection, the decriminalization of bankruptcy, the protection of shareholders before creditors, capital market creation, liberalization, the simplification of the termination of employment contracts, and support for the unemployed are some of the actions that may be taken to meet the governmental obligation $[9,34,35]$.

2) Finance: This field is one of the three main aspects of the entrepreneurial ecosystem [70]. Financial resources, public or private, must be available, visible, and accessible to all sectors of the ecosystem [63]. A well-developed financial market reduces the cost of capital acquisition by a company and facilitates the flow of money, which allows a company to grow faster [39].

3) Culture. This domain contributes significantly to the evolution of the entrepreneurial ecosystem and refers to the strengthening of informal institutions for entrepreneurs to feel secure in undertaking business activities. Successful entrepreneurs are usually people who have failed once or more before thriving [34]. For cultural change to occur and for people to face failure as a potentially beneficial outcome, entrepreneurship must be accorded high social priority. 
4) Support Services: These services may be classified into infrastructure, nongovernmental organizations, and supporting professions. Infrastructure groups include science parks, telecommunications conditions, transportation, logistics, and energy [35]. Non-governmental organizations denote accelerators, hubs, and incubators [7]. Supporting professions signify services that support business legalization, special commercial lawyers, accountants, consultants, suppliers, and funding institutions [35]. The university functions in the role of a consultant who has invested significant resources into the configuration of supporting mechanisms to increase innovation and entrepreneurship [23]. In several studies, the entrepreneurial ecosystem has been associated with the activities of universities and of public institutions and is linked to the success of new business projects [23]. An entrepreneurial university can increase the creation of new companies that promote competition and diversity [71]. Such activities can produce several externalities in demography, economy, infrastructure, culture, mobility, education, and social challenges. All these components will subsequently be reflected in productivity, CA, regional capacity, networks, and regional identities [25].

5) Human capital: Entrepreneurs who want to succeed must possess entrepreneurial skills in addition to requiring skilled workers. On the one hand, entrepreneurship education can provide the support needed for human capital training [35]. On the other hand, the most active areas are those that contain a supply of talented and skilled professionals [74].

6) Market: Two elements contribute greatly to new business capabilities having access to the opportunities offered by the market: a large company that provides resources, space, and commercial opportunities (contracts or initial customers); and a network. The network encourages the creation of new businesses from knowledge spillovers and is a major source of information, resources, and access to domestic and international markets [74].

\section{METHODS}

This study used a literature review and contextual techniques with regard to the role of actors within entrepreneurial ecosystems in the Creative Industry of Indonesia. The mapping of the role of the actors and a triangulation processing were carried out by using data from previous studies, online news, and government documentation related to regional competitive advantage, entrepreneurial ecosystems and Creative Industry of Indonesia. The results of the mapping were examined and analyzed.

\section{RESULTS AND DISCUSSION}

Indonesia commands a vast variety of natural resources, culture, and immense local wisdom and is capable of emerging as a major capital for the development of a creative economy. It is a large archipelagic country consisting of 17,504 islands full of diversity and cultural wealth. Around 1,068 ethnic groups and 665 regional languages are found throughout the archipelago. The nation's performing arts include at least 300 traditional dance styles. The natural resources and cultural multiplicity of Indonesia accord it great economic potential that can support the growth of ideas and promote the creativity of the community. Economic potential derived from the creative ideas of the society integrated with its cultural and natural diversity can create a variety of unique and inspired products that could easily support the growth of a creative economy. This cultural variety expresses itself in a wide range of Indonesian handicrafts and products in the creative economy and reveals the multifarious talents of the community. Romarina [58] articulates that a creative economy is related not only to the generation of added economic value but also to the production of supplementary social, cultural, and environmental values. 
The main input of the creative economy comprises infinite ideas and thinking skills. With a young population comprising 43\% ( 103 million people) of the population Indonesia can claim a strong human resource base on which to develop its creative economy, because young people generally hold greater imaginative and innovative power than an older population. However, the potential for work piracy, low purchasing power, inferior quality of creative economic output, and limited market access reduce the competitiveness of Indonesia's creative economy in global markets, especially in the ASEAN marketplace [75].

The Indonesian government has launched a blueprint for "Indonesia's Creative Economy," a new fiscal concept oriented toward creativity, culture, cultural heritage, and environment [5] aimed at improving the creative economy in Indonesia. To realize this design, the Department of Trade of the Republic of Indonesia has compiled a Creative Economy Development Plan 2009-2015 [46]. The Ministry of Trade is attempting to grow this creative industry by focusing on (i) creative and cultural business, (ii) creative industries, and (iii) intellectual property rights such as copyright. The economic inclination toward creative industry is a form of optimism for those who aspire to support the master plan for the acceleration and expansion of Indonesian economic development and to actualize Indonesia's vision of becoming an advanced country [5].

The 2009-2015 Creative Economy Development Plan is one of the government's efforts to face the period of transition into the third millennium, a time when the government must own core competencies capable of producing national CA. The availability of intellectual human capital that has creative, innovative, flexible, and entrepreneurial properties is one of the key factors of generating CA. The chief competencies of CA are physical, human, and organizational resources (organizational capital). Of these three types of resources, invisible assets derived from human resources elevate CA. Increased productivity toward CA is achieved through innovation-based efforts to strengthen the ability of human resources [5]. There is a palpable need for quality human resources with pioneering power and extraordinary creativity [46] if a creative economy is to be developed.

Therefore, an entrepreneurial ecosystem must be contemplated, apprehended, and constructed as a collaborative environment between actors who can support CA especially for Indonesia's creative industry. The functioning of various actors involved in the entrepreneurial ecosystem of the creative industry must be studied and analyzed to ascertain the manner in which each actor is positioned in the entrepreneurial ecosystem. The blueprint of the "2025 Creative Economy Development of the Ministry of Trade of the Republic of Indonesia" underpins the structure of the creative industry by forging a relationship between intellectuals, business ventures, and the government, a framework which is labeled the "triple helix" system. These three agents drive the birth of innovation, ideas, science, and technology vital for the growth of the creative industry in Indonesia. A close relationship, shared support, and a symbiosis of mutualism between the three actors with regard to the foundation and pillars of the creative economic model will produce a firm and sustainable creative economy [57]. Further, Bekraf [11] adds other players who are engaged in the development of the creative economy. These actors include the government, business people, academics, communities, and the media. An explanation of the role of each actor engaged in the entrepreneurial ecosystem of Indonesia's creative industry follows. The list conforms to Isenberg's model [35] combined with Bekraf's conception [11]:

Government. The government includes central and regional administrative units related to the development of the creative economy, as both are links of substance and executive relationships. The central government encompasses departments and agencies. Local 
governments include first-level local control units, second-level regional supervisory structures, and the lowest hierarchy of the regional administration.

The government's focus on the creative economy in Indonesia began only in 2006 with the appointment of the Ministries of Trade, Industry, and Tourism to oversee the creative economy through the Indonesia Design Power 2006-2010 program, which is a government plan to improve the CA of Indonesian products in the domestic market or for export goods that evince a national character. The government's attention was only attracted to the creative economy only after it obtained evidence that the creative economy contributed substantially to the national wealth. In 2011, the creative economy was contemplated by the Ministry of Tourism because it is closely related to the tourism sector. Afterwards, Presidential Decree No. 6/2009 was passed, and 2009 was declared Creative Indonesia Year [33].

In 2010, a digital platform called Indonesia's Creative Economy was created to serve as a forum of awareness for the Indonesian people with regard to the development of creative industries in the archipelago. On the other hand, the central government began an intense socialization drive for local governments to elicit the generation of data on exporters, importers, entrepreneurs, associations, and creative industry players, as well as formal and non-formal educational institutions. On December 21, 2011, the government formally established the Ministry of Tourism and Creative Economy based on Presidential Regulation No. 92 of 2011. The new ministry was strengthened by two Director Generals who were directly responsible for the development of creative industries in Indonesia: the Directorate General of Creative and Art-based Industry, and the Directorate General of Creative Industry based on Media, Design, and Science and Technology (science and technology) [31].

The first step in the development of creative industries within the Ministry of Tourism and Creative Economy was the formulation of a strategic plan for the development of tourism and the national creative economy. The plan's focused primarily on efforts to increase the quantity and quality of creative human resources and on strengthening institutional and market access for creative local production. This plan formed the foundation for the implementation of creative industry development programs and activities until 2014. In 2014, the Ministry of Tourism and Creative Economy revised the creative industry development plan up to 2025, and this blueprint was translated into the 2015-2019 creative industry development program. Based on the master plan for creative industry development up to 2025, the thrust of the creative industry development from 2015 to 2019 is to strengthen creative industries by emphasizing the achievement of CA gained from the excellence of natural, cultural, and human resources of high quality, as well as the imaginative utilization of science and technology. Further, institutions are to be bolstered to create a business climate conducive to the development of local creative industries [18].

On January 20, 2015, a new non-ministerial institution called the Creative Economy Agency (Bekraf) was formed through the Republic of Indonesia's Presidential Regulation Number 6 of 2015. This agency is responsible for the development of Indonesia's creative economy and is tasked with the strategic mission to promote innovation-based employment by creating an ecosystem that is favorable to its development [11]. Bekraf envisions Indonesia's growth into one of the world's major creative economic powers by 2030. To achieve this vision, Bekraf has designed six major missions:

1. Unite all the assets and combine the creative potential of Indonesia to achieve an independent creative economy.

2. Create a climate conducive to the development of creative industries. 
3. Encourage innovation in creative fields in which Indonesia can add value and gain international competitiveness.

4. Open the public's mind and inculcate general appreciation for all aspects related to the creative economy.

5. Build awareness and comprehension of intellectual property rights, including legal protection against copyright.

6. Design and implement specific strategies to place Indonesia on the map of the world's creative economy.

Bekraf is tasked with assisting the president in the formulation, establishment, coordination, and synchronization of policies for the creative economy. In executing this task, Bekraf organizes several functions:

1. The formulation, determination, and implementation of policies for the creative economy

2. The design and implementation of programs for the creative economy

3. The implementation of coordination and synchronization of planning and execution of policies and programs for the creative economy

4. The provision of technical guidance and supervision for the implementation of policies and programs for the creative economy

5. The discharge of guidance and support of all stakeholders in the creative economy

6. Communication and coordination with state institutions, ministries, non-ministerial government institutions, regional governments, and other related parties

7. The performance of other functions assigned by the president in relation to the creative economy.

To develop Indonesia's creative economy, various activities are undertaken such as establishing cooperation with Bukalapak in a commitment to advance creative economic actors to compete in the ASEAN economicc through a digital approach. A KUR (People's Business Credit) program will also be launched, and mothers will be empowered through the Mum Coding program with coding or programming skills to ease their participation in the creative economy industry.

Bekraf provides workshops for technical guidance to ensure that creative economic businessmen deserve additional capital to obtain funding for creative economy businesses. In this workshop, entrepreneurs undergo training in financial management. The Creative Economy Fund or Dekraf was formed as Bekraf's means of support to creative economic actors. Dekraf is one of Bekraf's priority programs to generate capital for creative actors. For its implementation, Dekraf cooperates with banks and non-banking financial institutions on the availability of capital. It is expected to become a collection of funding commitments to creative economic actors who will receive support in the form of loans, grants, and investments. Loans provided by the banks to creative economic actors are channeled through conventional and sharia schemes. Such loan schemes can be provided by non-banking financial institutions. Within the framework of cooperation with state-owned enterprises (SOEs), loan schemes can be provided through a partnership program which can be taken from a percentage of the company's profits every year. Dekraf is expected to collect corporate social responsibility commitments or sponsorships for the community development program from SOEs as grant schemes from companies. While in the investment framework or as equity, Dekraf will raise commitments from crowd-funding, venture capital, philanthropy, and public fundraising through IPOs on the Indonesian Stock Exchange [11]. 
In executing these duties and functions, Bekraf cooperates with the Central Statistics Agency (BPS), the Indonesian Institute of Sciences (LIPI), the Agency for the Assessment and Application of Technology (BPPT), and six universities: Gajah Mada University, Institute of Technology Bandung, University of Indonesia, Sepuluh Nopember Institute of Technology, Jakarta Institute of Arts, and Indonesian Institute of the Arts. The collaboration is intended to help Bekraf accomplish research programs related to creative economic statistics, the improvement of the Standard Classification of Indonesian Business Fields (KBLI), subsector surveys and information, market and product research, development of trend forecasts, and other subjects. Through this partnership, Bekraf is optimistic about creating an efficient and favorable creative economic ecosystem [11].

Therefore, the main roles of the government agencies in the development of a creative economy in Indonesia are:

1. As catalysts, facilitators, and advocates who provide the stimuli, challenges, and encouragement to steer business ideas toward higher competence levels. The support provided takes the form of the government's commitment to proportionally use its political power and to tender effective public administration services.

2. As regulators that produce policies related to industry, intermediation, resources, and technology. Authorized government agents can accelerate the development of creative industries if policies for a creative climate are efficiently applied.

3. As consumers, investors, and entrepreneurs. The government must empower state assets to be productive in the creative economy as an investor and must be invest in the industrial infrastructure. As a consumer, the government needs to revitalize its procurement policies and accord priority to the use of creative products. As an entrepreneur, the government has indirect authority over SOEs (BUMN).

4. As urban planners. Creativity will thrive in cities that can offer a creative climate. For creative economic development to operate effectively, creative cities must be developed in Indonesia. The government agencies will play a central role in the creation of creative cities which can accumulate and concentrate energy from creative individuals into a magnet that can attract individuals and other enterprises to operate businesses in Indonesia. Many cities in Indonesia such as Bandung, Jakarta, and Semarang have enough energy to be selected as candidates for development into creative cities.

Andersson and Henrekson [6] claim that policymakers can gain much from actively improving the formal and informal institutional framework. A favorable local institutional environment increases the odds of strategically important firms growing in or shifting into a region; it also increases an area's "readiness" to exploit the potential associated with hosting entrepreneurial and knowledge-intensive activities. There are many ways in which policymakers can improve the local institutional conditions. These include measures to reduce the regulatory burden and policies that streamline administrative processes pertaining to businesses. They also comprise local taxes, housing regulations, zoning laws, and the overall quality of public services, notably healthcare and schools [6]. Local regulations governing businesses should be efficient and transparent. Both business and government have embraced ecosystems as a concept to enhance entrepreneurship and innovation [2]. For a country to be competitive and to inculcate a strong entrepreneurial culture, its public policy must utilize the two concepts to form a structure of competitiveness and a framework for an entrepreneurial ecosystem [61].

The government casts a four-dimensional influence [11] in addition to spearheading the progress of Indonesia's creative economy:

1. Provision of superstructure: the availability of foundations and policies that underlie creative economic activities. 
2. Supply of infrastructure: physical/non-physical facilities and support for reactive economic activities.

3. Institutions: organizations formed by the government, and regulations that are made to support creative economic activities.

4. Synergy between factors: internal and external cooperation. Internal cooperation pertains to the collaboration between agencies in one local government or with other regional governments. External cooperation refers to the alliance between local government and other elements such as community, academia, and business enterprises.

Intellectuals. In the creative industry, intellectuals include instructors in educational institutions, cultural observers, artists, cultural and arts studios, individuals or study groups, and researchers, writers, and other figures in the domains of art, culture (values, philosophy), and science that are related to the development of creative industries.

Intellectuals act as agents who disseminate and implement science, art, and academic contributions that can be translated into the three roles, and to the functions of the tri-partite dharma of higher education [19]:

1. Education encourages the birth of Indonesia's creative generation with a mindset that supports the growth of initiative and work in the creative industry.

2. Research provides input on the policy model for developing creative industries and the requisite instruments, produces technologies that support efficient ways of working and resource use to make the national creative industry more competitive.

3. The academic community takes on the role of community service to form social institutions/structures that support the growth of the national creative industry.

University intellectuals are crucial to the development of knowledge and technology innovations that will be transferred to creative economy entrepreneurs. This strategy can be implemented as follows [19]:

1. Conducting preliminary research to test innovation and appropriate technology before socialization in creative economy entrepreneurs.

2. Creating and developing new technologies to support the construction of a creative economy.

3. Imparting education, training, and assistance to the creative economy in a sustainable manner.

4. Developing home industry technology in an effort to create a new creative economic incubator.

The university functions as a producer and transmitter of knowledge and provides leadership for the creation of entrepreneurial thought, actions, institutions, and what Audretsch calls 'entrepreneurial capital' [4, 25]. University performance is a relevant factor in shaping a region's capacity for innovation and its competitiveness [25]. Several examples of the role played by intellectuals and universities in transferring technology and in scientific and other research resulting in the development of creative industries may be observed in the community service program, which works with local governments by involving the right industry. The collaboration with LIPI in the Iptekda program, which aims to elevate the regional economy through the empowerment of creative MSMEs, is another instance that may be cited. The formation of creative industries can be even more successful with the full involvement of academics. This strategy can indirectly answer the government's problems of stimulating the growth and development of creative industries in Indonesia [19]. 
Community. A community is a social group composed of several environmental backgrounds that share the same interests and habitat. A community incorporates [11]:

1. Numerous creative economic actors and the comparison of the population of creative economic actors with the population in the area.

2. The dimension of age, whereby the longer the community life expected, the stronger the creative economy formed in an area.

3. Product scope, which pertains to the output of the actors and the creative economic community.

4. Affiliates, who are the networks owned by the community.

5. Events, which are activities carried out by the community based on the level of coverage.

6. Synergy between reactors, which involves activities carried out by two or more different subsector communities and with government, academia, and business parties.

In addition, the relationship between entrepreneurs and the community can be collaborative in achieving competitive goals that were previously defined and at the same time, it can create and transfer knowledge [3]. Knowledge spillovers can provide several benefits for companies by increasing their ability to innovate [4].

Human Capital. Business actors are entrepreneurs, investors, creators of new technology, as well as creative economy consumers. A creative business encompasses several dimensions [11]:

1. Business actors: comparison of creative business people (individuals) to total business people.

2. Economic contribution: the input of the creative economy sector to regional GRDP.

3. Ratio of creative business companies: a comparison of business units (corporations) that support the economy to the total business units (corporations).

4. Synergy between reactors: the internal symbiosis among business people and between business people and other forces such as the government, community, and academics in developing the economy.

Entrepreneurs may take on some pivotal roles in the development of a creative economy:

1. As creators of excellence and novel products and services, business owners can create new markets to absorb their products and services, and also create jobs for resourceful artists and innovators or other supporting individuals.

2. The role of community building and visionary entrepreneurship is like a motor that shapes a public space for the sharing of thoughts, of mentoring that can hone creativity in conducting business activities, in coaching or management training in the creative industry.

In executing such functions, businesses must use entrepreneurial skills and actions to innovate inventive products and services. They should likewise be adept at organizing, cooperating, diplomacy, facing failures, financial planning, and at mastering the technical context. Entrepreneurial action requires knowledge investment and is a key element of the entrepreneurial process [1] because of its ability to produce innovation [13]. Knowledge spillovers can create new entrepreneurial opportunities or find new business opportunities that have not been previously recognized [4]. This identification of entrepreneurial opportunities is deemed strategic if entrepreneurial actions are needed to achieve premeditated tactical competitiveness [40]. 
Media. According to Howkins [29] the creative economy includes advertising, publishing, television, and radio, all of which are aspects of media. The media encompasses both print and electronic output which cannot be separated from creativity of production and thus from the development of the creative economy. Media contributions to the creative economy in Indonesia can include the following:

1. Provision of significant economic assistance

2. Promotion of a positive business climate

3. Construction of the image and identity of the nation

4. Development of an economy based on renewable resources

5. Creation of positive social impact

As a source of information for the community, the media's role is to educate the nation. The creative economy in Indonesia can develop rapidly and profitably with the appropriate contribution of the media, which tries to provide new information every day in a variety of creative and innovative ways. Tourism is a sector of the creative economy in Indonesia that requires a very large media function. According to Nugroho [12] the role of media is vital to the promotion of Indonesian tourism. Information about tourist destinations is delivered through print, electronic, and online media, which can encourage domestic tourists to travel and can positively influence the increase of foreign tourist arrivals to Indonesia.

In addition, creative economic activities are closely related to an actions or events that are generally performed for the public such as theater, music concerts, and exhibitions. The development of the creative economy is inseparable from the role of the mass print and electronic media in disseminating news, issues, and the latest information about activities or events. The role of technology, such as the internet and smartphones, accelerates the spread of news and helps people access information anytime and anywhere [11].

Culture. Culture is an important component of the entrepreneurial ecosystem as revealed by Aldrich and Fiol [28] who refer to historical and locally embedded "entrepreneurship cultures" where collective values and norms are positively oriented toward entrepreneurship. Such a culture can be important in fostering a social environment that is conducive for entrepreneurs [6]. The influence of such a culture does not only apply to associated local regulations and to the attitudes of elected local politicians and bureaucrats. Values and norms have broad-ranging effects that permeate many levels of an economy. In Indonesia's entrepreneurial ecosystem, culture is one of the main sources of creative product creation. The wealth and value of local wisdom are unique to the products of Indonesia's creative economy, especially with regard to the craft, fashion, and culinary sectors. These products were inherited from ancestors and disseminated through generations. Entrepreneurship attributes such as value, culture, and mindset are learned and embedded in the character of each ensuing generation. This relationship certainly influences the regional entrepreneurship culture in the ecosystem of an area [6]. Therefore, a particular region can influence entrepreneurial activities through a shared culture or a set of formal and informal rules. A sustainable entrepreneurial culture can be formed in areas where entrepreneurship is considered to accord valuable rewards and entrepreneurs are viewed as role models [26].

Sorenson and Audia [60] report varied ways in which the effects of a local entrepreneurship culture are materialized and are maintained over time. One mechanism runs through the role of model effects, which may take at least three forms: first, the sheer observation of a high density of entrepreneurs in one's local environment may stimulate entrepreneurial behavior by inducing motivation and self-confidence e.g.,., with reference to notions like "if they can do it, I can too"; second, in regions with a strong entrepreneurship culture, entrepreneurs are 
accorded a high social status, which may trigger increased entrepreneurial endeavors; third, a high local density of role model entrepreneurs automatically translates into a greater concentration of people who have experience in running businesses; a local abundance of knowledge about the practice of entrepreneurship is thus available. This advantage increases the odds for local inhabitants to acquire entrepreneurial skills and to become entrepreneurs [6]. In a competitive environment, entrepreneurs are alert to opportunities and contribute to the regional economic growth [26]. The nurturing of a strong entrepreneurial culture will bolster the continuity of the entrepreneurial ecosystem of Indonesia's creative economy in creating CA.

The actors of the entrepreneurial ecosystem developed by Bekraf are different from those of Isenberg's entrepreneurial ecosystem model $[34,35]$. Bekraf's model lacks at least two factors: supporting professions and markets.

1. Supporting Professions: These include business legalization, lawyers, accountants, consultants, suppliers, and funding institutions [34; 35]. Creative economies advance ideas that can be exploited into economic potential. Thus, the role of law in protecting ideas is very important, and is equivalent to the protection offered by IPR. Therefore, the registration of IPRs on products has certain proportions. The creative economy in Indonesia must be able to build a strong eastern foundation because in the eastern world, IPR must grasp the values that emanate from the local cultural wisdom of togetherness and sharing.

2. Markets: Two elements contribute greatly to a start-up's ability to access opportunities offered by the market. The first is a large company that provides commercial resources, space, and opportunities for the start-up; for instance, its first contract or initial customer. The second element is the network. These two elements encourage the creation of new businesses from knowledge spillovers and are the main sources of information, resources, and access to domestic and international markets [74].

3. One of the problems facing Indonesia's creative economy is its limited access to markets and to networks of business people. High quality creative products will certainly be useless if they are not absorbed by the market. The tendency is that creative economy business actors only produce products that have already captured certain markets without being able to expand their markets. Therefore, the role of the market is crucial to the expansion and sustainability of Indonesia's entrepreneurial ecosystem of the creative economy, which will ultimately lead to its CA.

These two components must be considered by other actors engaged in the economic entrepreneurial ecosystem of Indonesia, especially the governments that are accorded the power of implementing policies and regulations. The existence of IPR guarantees that creative Indonesian products will help to improve product CA because such goods are protected from plagiarism. At the same time, the existence of easy and wide market access will allow businesses to reach target markets and make expansion easier to achieve.

\section{CONCLUSION}

Implications for Entrepreneurial Ecosystems. The concept of the knowledge-based entrepreneurship ecosystem (KBEE) has developed over the past few years. This theory can be used to expand and enhance Indonesia's competitive position [72]. Indonesia's creative economy must thus be converted into an entrepreneurial ecosystem-based knowledge or KBEE. In the context of a knowledge-based economy, KBEE can be understood to be a mechanism that requires mediation between the creation of knowledge and innovation, and its transformation into economic activities and values [72]. The transfer of knowledge will create 
entrepreneurship of higher quality. The superior capabilities that ensue will, in turn, help the production of original and innovative products and services.

Implications for Competitive Advantage. Increasingly, CA vests in companies, regions, and countries that seek to intensify their direct and indirect capabilities to generate intensive knowledge and to increase productivity, innovation, and the formation of new companies that accompany the integration of local and global value chains [17, 24]. The collaboration of institutions in the environment with regard to knowledge transfer, productive entrepreneurship, and innovation tend to increase CA. This outcome occurs because local CA can be obtained from knowledge and innovation $[15,22,51]$. The major challenge for developed and developing countries is to use scientific knowledge to improve competitiveness and to create a new international division of labor [15].

Implications for Creative Economy Policy. The following strategies and policies should be considered to encourage the quality of competitiveness in a creative economy:

1. Stability should be maintained in macroeconomic conditions. To increase the capacity and sustainable edge of the creative economy, the Indonesian government must continue to augment its commitment to support the optimization of competitiveness. This strategy will drive quality, productivity, and economic growth, especially in fundamental sectors such as industrial development; agriculture; marine industries and fisheries; energy; infrastructure; banking development; micro, small, and medium enterprises; health; entrepreneurship; and cooperatives [58].

2. The development of a creative economy should be grounded in local wisdom. Creative economic development should focus on the utilization and on the optimization of resources and regional competencies by exploring the potential of a productive economy that is competitive (knowledge-based economy) [72] and is based on regional resources (local resources-based economy).

3. The successful development of the creative economy entrepreneurship ecosystem requires strong collaboration between the policies of the local government and the performance of community networks and economic actors. The entrepreneurial ecosystem will improve the quality of entrepreneurship to always be innovative [8]. High productivity reflects greater competitiveness, which has the potential to produce increased economic growth [52].

Directions for Future Research. Future researchers can validate the role of the actors that have been studied in this paper. Subsequent research initiatives can use the quantitative research methods employed in this study to measure the role of each actor and its contribution to the entrepreneurial ecosystem of the creative economy in Indonesia. In addition, it is possible to further develop the models in this study in terms of variables involved or for other types of industrial sectors. Future research projects can develop models to determine the causal relationships among actors involved in the entrepreneurial ecosystem, especially pertaining to their impact on CA.

\section{References}

Acs, Zoltan, Erkko Autio and László Szerb, 2014. "National Systems of Entrepreneurship: Measurement Issues and Policy Implications.” Research Policy 43, 3 (2014): 476-494.

Acs, Zoltan, Erik Stam, David B. Audretsch and Allan O'Connor, 2017. "The Lineages of the Entrepreneurial Ecosystem Approach." Small Business Economics 49, 1 (2017): 1-10.

Adão Flores, Elsa Pereira and Henrique Graça, 2017. "Entrepreneurial Ecosystems” In Knowledge Transfer to and within Tourism, edited by Noel Scott, Marcella De Martino and Mathilda Van Niekerk, pp. 97-111. Emerald Publishing Limited. 
Agarwal, Rajshree, David Audretsch and M. B. Sarkar, 2010. "Knowledge spillovers and strategic entrepreneurship." Strategic Entrepreneurship Journal 4, 4 (2010): 271-283.

Ahmad Kamil, 2015. “Indonesian Creative Industry: Industry Performance Analysis Approach," Media Trend 10, 2 (2015): 207-225

Andersson, Martin, and Magnus Henrekson, 2014. "Local competitiveness fostered through local institutions for entrepreneurship." In The Oxford handbook of local competitiveness, edited by Edited by David B. Audretsch, Albert N. Link and Mary L. Walshok, pp. 145-190. Oxford: Oxford University Press.

Arruda, Carlos Alberto Arruda de Oliveira, Vanessa Silva Nogueira and Vinícius Costa, 2013. “The Brazilian Entrepreneurial Ecosystem of Startups: An Analysis of Entrepreneurship Determinants in Brazil as Seen from the OECD Pillars," Journal of Entrepreneurship and Innovation Management 2, 3 (2013): 17-57

Audretsch, David B. and Iñaki Peña-Legazkue, 2012. "Entrepreneurial Activity and Regional Competitiveness: An Introduction to the Special Issue," Small Business Economics 39, 3 (2012): 531-537

Autio, Erkko, Martin Kenney, Philippe Mustar, Don Siegel and Mike Wright, 2014. "Entrepreneurial Innovation: The Importance of Context." Research Policy 43, 7 (2014): 1097-1108.

Bekraf, 2015. "creativity-based economy," https://www.ekon.go.id/berita/view/ekonomi-berbasiskreativitas.1659.html Senin, 07 September 2015 - 20:03. accessed on March 20, 2018

Bekraf, 2017. "creative economic agency creative economy outlook."

http://www.bekraf.go.id/berita/page/12/badan-ekonomi-kreatif-creative-economy- outlook-2017-conference. accessed on March 20, 2018

Benitoramio nugroho, 2012. "Social Media Nation: The Power of Social Media for Creative Industry \& Small Business," http://benitoramio- nugroho.blogspot.com/2012/11/media-sosial-pilar-baru-pendorong.html. accessed on March 20, 2018.

Bird, Barbara, Leon Schjoedt and J. Robert Baum, 2012. “Editor's Introduction. Entrepreneurs' Behavior: Elucidation and Measurement," Entrepreneurship Theory and Practice 36, 5 (2012): 889-913.

Caiazza, Rosa, Aileen Richardson and David Audretsch, 2015. "Knowledge Effects on Competitiveness: From Firms to Regional Advantage," The Journal of Technology Transfer 40, 6 (2015): 899-909.

Carayannis, Elias G. and David F.J. Campbell, 2011. “Open Innovation Diplomacy and a 21st Century Fractal Research, Education and Innovation (FREIE) Ecosystem: Building on the Quadruple and Quintuple Helix Innovation Concepts and the 'Mode 3' Knowledge Production System," Journal of the Knowledge Economy 2, 3 (2011): 327.

Castilla-Polo, Francisca, Dolores Gallardo-Vázquez, M. Isabel Sánchez-Hernández and María del Consuelo RuizRodríguez, 2017. "Cooperatives as Responsible and Innovative Entrepreneurial Ecosystems in Smart Territories: The Olive Oil Industry in the South of Spain." In Handbook of Research on Entrepreneurial Development and Innovation Within Smart Cities, pp. 459-490. IGI Global, 2017.

Cooke, Philip, 2016. "The Virtues of Variety in Regional Innovation Systems and Entrepreneurial Ecosystems." Journal of Open Innovation: Technology, Market, and Complexity 2, 1 (2016): 13.

Creative Economy: "Medium-Term Action Plan 2015-2019. "Ministry of Tourism and Creative Economy RI. http. gov.indonesiakreatif.net

Dewi Eka Murniati, 2009. "Role of Higher Education in Triple Helix as an Effort to Develop Creative Entrepreneurs. "National Seminar" The Role of Vocational Education in Creative Industry Development" PTBB FT UNY 21 November 2009.

Diego Alex Gazaro dos Santos, Aurora Carneiro Zen and Vitor Klein Schmidt,2017. "Entrepreneurship Ecosystems and the Stimulus to the Creation of Innovative Business: A Case in the App Industry in Brazil." Journal of Research in Business, Economics and Management 8, 5 (2017): 1537-1543.

Dubina, Igor N., David FJ Campbell, Elias G. Carayannis, Anna A. Chub, Evangelos Grigoroudis and Olga V. Kozhevina, 2017. "The balanced development of the spatial innovation and entrepreneurial ecosystem based on principles of the systems compromise: a conceptual framework." Journal of the Knowledge Economy 8, 2 (2017): 438-455.

Eggink, Maria, 2013. "The Components of an Innovation System: A Conceptual Innovation System Framework." Journal of Innovation and Business Best Practices 2013 (2013). 
Purbasari, R., Wijaya, C., \& Rahayu, N. (2019). Entrepreneurial Ecosystem and Regional Competitive Advantage: A Case Study on the Creative Economy of Indonesia. Advances in Social Sciences Research Journal, 6(6) 92-110.

Fernández Fernández, M. Teresa, Francisco J. Blanco Jiménez and Juan R. Cuadrado Roura, 2015. “Business incubation: innovative services in an entrepreneurship ecosystem." The Service Industries Journal 35, 14 (2015): 783-800.

González-Pernía, José L., Iñaki Peña-Legazkue and Ferran Vendrell-Herrero, 2012. “Innovation, Entrepreneurial Activity and Competitiveness at a Sub-national Level," Small Business Economics 39, 3 (2012): 561-574

Guerrero, Maribel, David Urbano and Alain Fayolle, 2016. "Entrepreneurial activity and regional competitiveness: evidence from European entrepreneurial universities." The Journal of Technology Transfer 41, 1 (2016): $105-131$.

Huggins, Robert and Nick Williams, 2011. "Entrepreneurship and Regional Competitiveness: The Role and Progression of Policy." Entrepreneurship \& Regional Development: An International Journal 23, 9-10(2011): 907932

Huggins, Robert, 2013. "Regional Competitiveness: Theories and Methodologies for Empirical Analysis." JCC: The Business and Economics Research Journal 6, 2 (2013): 155-172

Howard E. Aldrich and C. Marlene Fiol, 1994. "Fools Rush in? The Institutional Context of Industry Creatio". Academy of Management Review Vol. 19, No. 4

Howkins, John, 2001. “The Creative Economy: How people Money make from ideas”. London: Allen Lane, 2001.

Iansiti, Marco, and Roy Levien, 2004. "The Keystone Advantage: What the New Dynamics of Business Ecosystems Mean for Strategy, Innovation, and Sustainability”. Cambridge: Harvard Business Press, 2004.

Indonesian Creative Economy Development Plan 2009-2015.http://dgi-indonesia.com/wpcontent/uploads/2009/05/buku-1-rencana-pengembangan-ekonomi-kreatif-indonesia- 2009.pdf

Inga, Erina, Vladimir Shatrevich and Elina Gaile-Sarkane, 2017. "Impact of Stakeholder Groups on Development of a Regional Entrepreneurial Ecosystem." European Planning Studies 25, 5 (2017): 755-771.

Instruction of the President of the Republic of Indonesia No. 6 of 2009 concerning the Development of Creative Economy, Inpres No.6/2009, www.kemenpar.go.id/userfiles/file/7193 2610-Inpres 6Tahun2009.pdf

Isenberg, Daniel, 2010. "The Big Idea: How to Start an Entrepreneurial Revolution”. Harvard Business School Publishing Corporation, 2010.

Isenberg, Daniel, 2011. “The Entrepreneurship Ecosystem Strategy as a New Paradigm for Economic Policy: Principles for Cultivating Entrepreneurship." PhD Dissertation, Institute of International European Affairs, Dublin, 2011, pp. 1-13.

Ketels, Christian, Göran Lindqvist and Örjan Sölvell, 2012. "Strengthening clusters and competitiveness in Europe. The Role of Cluster Organisations." (The Cluster Observatory, Center for Strategy and Competitiveness, Stockholm School of Economics, Stockholm, 2012).

Kim, Hyesun, Mangyu Choi, Byunghoon Jeon and Hyoungro Kim, 2016. "A study on the big data business model for the entrepreneurial ecosystem of the creative economy." In Advances in parallel and distributed computing and ubiquitous services, edited by James J. Park, Gangman Yi, Young S. Jeong, Hong Shen, pp. 185-190. Singapore: Springer, 2016.

kompas.com, 2017. Recognizing the Role of the State in Creative Industries," https://nasional.kompas.com/read/2017/12/05/06080321/menyadari-peran-negara- dalam-industri-kreatif. accessed on March 23, 2018

Kshetri N, 2014. "Developing Successful Entrepreneurial Ecosystems: Lessons from a Comparison of an Asian Tiger and a Baltic Tiger." Baltic Journal of Management 9, 3 (2014): 330-356.

Kuratko, Donald F. and David B. Audretsch, 2009. "Strategic entrepreneurship: exploring different perspectives of an emerging concept." Entrepreneurship Theory and Practice 33 no. 1 (2009): 1-17.

Liao, Shu-Hsien, Chih-Chiang Chen, Da-Chian Hu, Yu-chun Chung and Min-Ju Yang, 2017. “Developing a Sustainable Competitive Advantage: Absorptive Capacity, Knowledge Transfer and Organizational Learning," The Journal of Technology Transfer 42, 6 (2017): 1431-1450.

Ling, Ya-Hui, 2013. "The Influence of Intellectual Capital on Organizational Performance-Knowledge Management as Moderator." Asia Pacific Journal of Management 30, 3 (2013): 937-964.

Mack, Elizabeth and Heike Mayer, 2016. "The Evolutionary Dynamics of Entrepreneurial Ecosystems." Urban Studies 53, 10 (2016): 2118-2133. 
Mason, Colin and Ross Brown, 2014. "Entrepreneurial ecosystems and growth oriented entrepreneurship." Final Report to OECD, Paris 30, 1 (2014): 77-102.

Moore, James F, 1993. "Predators and prey: a new ecology of competition." Harvard Business Review 71, 3 (1993): 75-86.

Nasir dan Yuslinaini, 2017." Analysis of Creative Industry Mapping of Handicraft Subsector and Impact of Increasing Community Welfare in Aceh Besar District." Jurnal Ekonomi dan Manajemen Teknologi 1, 1(2017): 1117

Nicotra, Melita, Marco Romano, Manlio Del Giudice and Carmela Elita Schillaci, 2017. "The Causal Relation Between Entrepreneurial Ecosystem and Productive Entrepreneurship: A Measurement Framework." The Journal of Technology Transfer 43, 3 (2017): 640-673

Peter F. Drucker, 1985. "Innovation and Entrepreunership Practice and Principles". New York, Harper \& Row, Publiser, Inc

Piergiovanni, Roberta, Carree, Martin A. and Santarelli, Enrico, 2009. "Creative industries, new business formation and regional economic growth", Jena Economic Research Papers (2007-2014), Max-Planck-Institut für Ökonomik und Universität Jena

Popy Rufaidah and Sutisna Kapabilitas, 2015. “Dynamic West Java Creative Industries SMEs.” Sosiohumanior 17,1 (2015): 60-66

Porter, Michael E, 1990. The Competitive Advantage of Nations. New York: Free Press.

Porter, Michael E., 2000. "Locations, Clusters, and Company Strategy." In The Oxford Handbook of Economic Geography, edited by Gordon L. Clark, Maryann P. Feldman and Meric S. Gertler, pp. 253-274. Oxford: Oxford University Press.

Purbasari, R., Drahen, P., \& Wijaya, C, 2019. “An Entrepreneurial Ecosystems Approach to Encouraging Local Economic Development through a Village-Owned Enterprises Policy (A Case Study of Indonesian Village-Owned Enterprises (BUMDes))". Archives of Business Research, 7(4), 254-264

Republic of Indonesia Presidential Regulation Number 72 of 2015 concerning the Creative Economy Agency, peraturan.go.id/perpres/nomor-72-tahun-2015.html

R. Camagni, 2003. “Regional Cluster, Regional Competencies, And Regional Competition. the International Conference on "Cluster management in structural policy - International experiences and consequences for Northrhine-Westfalia", Duisburg, december 5th, 2003-11-26

R.Celinni and Soci, Anna, 2002. "Pop competitiveness”. BNL Quarterly Review, no. 220, March 2002.

Rochmat Aldy Purnomo, 2017. "The Creative Economy "Indonesian Development Pillar" is published independently in www.nulisbuku.com, accessed on March 23, 2018

Romarina, Arina, 2016. "Economic Resilience in Creative Industries To Face Globalization in the Context of National Resilience." Jurnal Ilmu Sosial 15, 1 (2016): 35-52.

Scott, Allen and Michael Storper, 2003. "Regions, globalization, development." Regional studies 37, 6-7 (2003): 579 593.

Sorenson, Olav and Pino G. Audia, 2000. "The social structure of entrepreneurial activity: Geographic concentration of footwear production in the United States, 1940-1989." American Journal of Sociology 106, 2 (2000): 424-462.

Soto-Rodríguez, Edgar, 2015. "Entrepreneurial Ecosystems as a Pathway Towards Competitiveness: The Case of Puerto Rico." Journal of Competitiveness Studies 23, 1/2 (2015): 55.

Spigel, Ben, 2017. "The Relational Organization of Entrepreneurial Ecosystems." Entrepreneurship Theory and Practice 41, 1 (2017): 49-72.

Stam, Erik, 2015. "Entrepreneurial Ecosystems and Regional Policy: A Sympathetic Critique." European Planning Studies 23, 9 (2015): 1759-1769.

Stam, Erik and Ben Spiegel, 2016. "Entrepreneurial Ecosystems," Discussion Paper Series 16, Utrecht School of Economics, Tjalling C. Koopmans Research Institute, 2016.

Toffler, Alvin, 1980. "The Third Wave”. New York: William Morrow and Company, 1980.

Triawan Munaf, 2017. "bekraf for pre startup," http://www.bekraf.go.id/berita/page/12/bekraf-forpre-startup-2017. accessed on March 20, 2018 
Tsvetkova, Alexandra, 2015. “Innovation, Entrepreneurship, and Metropolitan Economic Performance: Empirical Test of Recent Theoretical Propositions." Economic Development Quarterly 29, 4 (2015): 299-316.

Turok I, 2004. "Cities, regions and competitiveness", Regional Studies38, 1061-1075.

Welter Friederike, 2011. "Contextualizing Entrepreneurship: Conceptual Challenges and Ways Forward." Entrepreneurship: Theory and Practice 35, 1 (2011): 165-184.

World Economic Forum, 2015. “The Global Competitiveness Report”. New York: Oxford University Press, 2015

Wright, Mike, Paul Westhead and Deniz Ucbasaran, 2007. "Internationalization of Small and Medium-sized Enterprises (SMEs) and International Entrepreneurship: A Critique and Policy Implications." Regional Studies 41, 7 (2007): 1013-1030.

Yagoub, Entezari, 2015. “Building Knowledge-based Entrepreneurship Ecosystems: Case of Iran.” Procedia - Social and Behavioral Sciences 195 (2015): 1206-1215.

Zahra, Shaker A. and Satish Nambisan, 2012. "Entrepreneurship and Strategic Thinking in Business Ecosystems." Business Horizons 55, 3 (2012): 219-229.

Zahra, Shaker A., Mike Wright and Sondos G. Abdelgawad. "Contextualization and the Advancement of Entrepreneurship Research.” International Small Business Journal 32, 5 (2014): 479-500.

Zaini, Afrizal Woyla Saputra, 2011. "The Low Competitiveness of Indonesian Countries Against Developed Countries," http://afrizalwszaini.wordpress.com/2011/05/28/rendahnya- daya-saingnegara-indonesiaterhadap-negara-negara-maju/, accessed on 28 February 2018 